\title{
Jean-Jacques Lefrère, Steve Murphy, Famille maudite, poètes maudits
}

\section{Ida Merello}

\section{Q OpenEdition}

1 Journals

\section{Edizione digitale}

URL: http://journals.openedition.org/studifrancesi/33492

DOI: 10.4000/studifrancesi.33492

ISSN: 2421-5856

\section{Editore}

Rosenberg \& Sellier

\section{Edizione cartacea}

Data di pubblicazione: 1 décembre 2005

Paginazione: 667

ISSN: 0039-2944

\section{Notizia bibliografica digitale}

Ida Merello, «Jean-Jacques Lefrère, Steve Murphy, Famille maudite, poètes maudits», Studi Francesi [Online], 147 (XLX | III) | 2005, online dal 30 novembre 2015, consultato il 18 avril 2021. URL: http:// journals.openedition.org/studifrancesi/33492 ; DOI: https://doi.org/10.4000/studifrancesi.33492

Questo documento è stato generato automaticamente il 18 avril 2021.

\section{(c) (i) (9)}

Studi Francesi è distribuita con Licenza Creative Commons Attribuzione - Non commerciale - Non opere derivate 4.0 Internazionale. 


\title{
Jean-Jacques Lefrère, Steve Murphy, Famille maudite, poètes maudits
}

\author{
Ida Merello
}

\section{NOTIZIA}

JEAN-JACQUES LEFRÈRE, STEVE MURPHY, Famille maudite, poètes maudits, «Histoires littéraires», juill.-août-sept. 2004, n 19, pp. 28-58

1 Gli Autori rendono conto di alcuni inediti di Rimbaud e di Verlaine, venduti all'asta nel maggio 2004, tra cui spiccano Famille maudite, versione sconosciuta di Mémoire di Rimbaud, e una lettera inedita di Verlaine a Victor Hugo, scritta poco dopo il ferimento di Rimbaud, che viene riportata nel testo. Gli autori si interrogano quindi sulla datazione di Famille maudite rispetto a Mémoire, propendendo per un'anteriorità della prima, e mostrano l'estremo interesse delle varianti. Vengono inoltre segnalati altri documenti rimbaldo-verlainiani (a parte un manoscritto di trascrizione di Oraison du soir che gli autori stessi hanno smascherato come falso e fatto ritirare dalla vendita): ossia un foglio in cui Verlaine enumera le dediche che vorrebbe applicare alla sua composizione Les Vaincus; i manoscritti di Crimen Amoris e di Don Juan pipé di Verlaine, alcune poesie dello stesso Verlaine con varianti sensibili rispetto alla trascrizione nelle raccolte, e tre lettere, accompagnate da testi poetici, indirizzate alla suocera nel tentativo di riannodare con la famiglia. 